\title{
Stakeholder Management and Program Planning in German Public Theaters
}

\author{
Sabine Boerner, Johanna Jobst
}

University of Konstanz

Taking the example of a German public professional theater, this study is the first to analyze how stakeholder interests are managed in the process of program planning. We address the following questions: (1) What are the goals and interests of the most influential stakeholders? (2) How are these goals and interests reflected by theater management when deciding the season's program? (3) Which strategies does theater management apply to balance conflicting stakeholder goals and interests? Results of our qualitative study identify five decisions to be made with regard to program planning: selection of the season's theme, plays, stage directors, cast, and chronological order of productions. Four strategies of balancing conflicting stakeholder goals and interests are identified: setting priorities, combining stakeholder interests, focusing on neutral goals, and developing audiences.

Keywords: goal conflict, program planning, public theater, stakeholder theory, strategic management

A CCORDING TO EMPIRICAL RESEARCH, organizations that effectively manage their stakeholder relationships outperform those that do not, whether in the for-profit sector, the nonprofit sector, or the public sector (Roman, Hayibor, and Agle, 1999;

We gratefully acknowledge the collaboration of Tobias Wettemann, who contributed in conducting the interviews. We also benefited greatly from the insights of four anonymous reviewers.

Correspondence to: Sabine Boerner, University of Konstanz, Fach 88, Universitaetsstrasse 10, 78457 Konstanz, Germany. E-mail: Sabine.Boerner@uni-konstanz.de 


\begin{tabular}{c} 
Program \\
planning-that is, \\
selecting and \\
scheduling \\
productions and \\
performances for \\
the season-has \\
been identified as a \\
core issue of \\
strategic decision \\
making in theaters. \\
\hline
\end{tabular}

Ruf and others, 2001; Orlitzky, Schmidt, and Rynes, 2003; Choi and Wang, 2009). Stakeholder analysis, however, has rarely been applied to professional theaters. Existing studies on strategic management in theaters mainly focus on organizational structure (Auvinen, 2001; G. B. Voss, Sirdeshmukh, and Z. G. Voss, 2008), marketing (Gainer and Padanyi, 2002; Rentschler, Radbourne, Carr, and Rickard, 2002), strategic orientation (G. B. Voss and Z. G. Voss, 2000; Z. G. Voss and G. B. Voss, 2000), or strategic choices (Gilhespy, 1999; Tajtáková, 2006b). Recently, Voss, Voss, and Moorman (2005) and Schulenburg (2006) have applied the multiple stakeholder approach (Freeman, 1984) to theater management.

Program planning - that is, selecting and scheduling productions and performances for the season-has been identified as a core issue of strategic decision making in theaters (DiMaggio, 1987). Although the determinants of program decisions have been investigated in some studies (Martorella, 1977; Pierce, 2000; Assassi, 2007), insights into the nature of the decision-making process in theaters are rare. In particular, stakeholder interests in program planning have not yet been analyzed.

Against this background, the present study analyzes how stakeholder interests are managed in the process of theater program planning. Most studies on theater management have been conducted in the United States; given the rich theater tradition in Europe, the focus of our analysis is on public theaters in Germany. We address the following questions: (1) What are the goals and interests of the most influential stakeholders in German public professional theaters? (2) How are these goals and interests reflected by theater management in the process of selecting the seasonal program? (3) Which strategies are applied by theater management to balance conflicting stakeholder goals and interests?

In the first part of this article, drawing on Schulenburg's (2006) application of stakeholder theory to German public theaters, we identify the most relevant theater stakeholders: local government, theater management, the audience, and artistic employees. By reviewing the literature on the German theater system, we identify the main goals and interests of these stakeholders. The second part presents results of a qualitative analysis in a German public theater. We first give a brief description of the program planning process, that is, the subjects of decision making and their respective interdependences. Second, we analyze how theater management considers stakeholder goals when planning the season program. Third, we analyze which strategies are applied by theater management to balance conflicting stakeholder goals.

\section{Stakeholder Interests of Public Theaters in Germany}

Due to the decentralized structure of historical princedoms and electorates (Haunschild, 2003), Germany has about 145 professional 
public theaters, which are mainly owned by the local or the federal community. Because the earned income of these theaters accounts for only 18.5 percent of their annual budget on average (Deutscher Buehnenverein, 2010), they are supported by public owners with a total of about 2 billion euros per annum (Statistische Aemter des Bundes und der Laender, 2008). Theater managers thus are responsible to their funding agency for both artistic production and use of the theater's budget. Nevertheless, the policy mandate a theater receives from its funding agency usually is a very general statement (Hoegl, 1995; Schugk, 1996), such as "enriching the cultural environment through artistic achievement" (Turbide and Laurin, 2009, p. 56).

Schulenburg (2006) was the first to apply stakeholder theory to professional public theaters in Germany. She analyzed the theaters' environments and identified a variety of potential stakeholders: funding agencies (local government, sponsors), the audience, the public (media, critics), suppliers (authors, workshops), competitors (other regional cultural organizations, television), and the theater itself (theater management, artistic employees). By using the relationship attributes identified by Mitchell, Agle, and Wood (1997)—power, legitimacy, and urgency-Schulenburg (2006) ranked the stakeholders according to their level of influence on the theater. Local government, theater management, the audience, and the artistic employees were identified as the most significant stakeholders.

According to the literature, stakeholder goals and interests may be complementary, neutral, or competing (Vahs and Schäfer-Kunz, 2007). To determine the relationship between stakeholder goals in German theaters, we identify the main goals and interests of the most relevant stakeholders based on a literature review (see Table 1).

\section{Local Government}

German public theaters are expected to fulfill both cultural and educational functions (Eikhof and Haunschild, 2007). According to a theater's communal mandate, the local government's interest is to assure ambitious productions, that is, "to stage dramas of artistic and educational, rather than purely entertainment value..., and to offer a different drama every night, drawing on a standing repertory of 15-30 plays for a season" (Eikhof and Haunschild, 2007, p. 527). By claiming productions of high artistic quality, the local government wants to establish a certain image for the theater while also reaching a broad public, within the limits of economic efficiency.

\section{Theater Management}

The main interest of a theater's management lies in implementing its artistic vision by staging productions of high artistic quality.

\section{According to the literature, stakeholder goals and interests may be complementary, neutral, or competing.}


Table 1. Summary of the Orientation of Stakeholders in German Public Theaters

\begin{tabular}{lccccc}
\hline & \multicolumn{4}{c}{ Goals and Interests } \\
\cline { 2 - 5 } & $\begin{array}{l}\text { Artistic } \\
\text { Excellence }\end{array}$ & $\begin{array}{l}\text { Educational } \\
\text { Functions }\end{array}$ & Entertainment & $\begin{array}{l}\text { Economic } \\
\text { Efficiency }\end{array}$ & $\begin{array}{l}\text { Other } \\
\text { Concerns }\end{array}$ \\
\hline $\begin{array}{l}\text { Local government } \\
\text { Theater mangement }\end{array}$ & $\mathrm{X}$ & $\mathrm{X}$ & & $\mathrm{X}$ & $\begin{array}{l}\text { Image } \\
\text { Reputation } \\
\text { Social hedonism, } \\
\text { arousal of } \\
\text { emotions } \\
\text { Artistic employees }\end{array}$ \\
& $\mathrm{X}$ & $\mathrm{X}$ & $\mathrm{X}$ & & $\begin{array}{c}\text { Employability } \\
\text { (reputation, } \\
\text { social network) }\end{array}$ \\
\hline
\end{tabular}

Within the German arts system, the so-called Kunstfreiheit (freedom of art) grants management the right to make decisions according to its own understanding of theater as art and without external interference (Eikhof and Haunschild, 2007). In addition, theater managers strive for personnel and institutional reputation.

\begin{tabular}{c}
\hline Like theater \\
management, \\
artistic employees \\
(actors, stage \\
designers, costume \\
advisers, and \\
musicians) are \\
particularly \\
concerned about \\
artistic \\
aspirations and \\
expectations.
\end{tabular}

\section{Audience}

Why does someone choose to attend a live theater performance? In a comprehensive literature review, Bouder-Pailler (1999) identified a broad range of motives-both intrinsic, or sought for its own sake, and extrinsic as a means of achieving another aim. According to the author, four dimensions underlie these motives: People visit the theater to (1) interact socially with their reference group as well as to show that they belong to a specific group (social hedonism), (2) be educated and develop themselves intellectually (intellectual enrichment), (3) engage in imaginative and emotional experiences (arousal of emotions), and (4) have a good time (entertainment). Compared to other theater stakeholder groups, however, "the audience" is less homogeneous; there is not one audience but many (DiMaggio, Useem, and Brown, 1978), including occasional theatergoers or tourists and loyal subscribers.

\section{Artistic Employees}

Like theater management, artistic employees (actors, stage designers, costume advisers, and musicians) are particularly concerned about artistic aspirations and expectations. They also seek opportunities to achieve individual reputation and build a social network with colleagues, directors, dramaturges, and theater managers (Haunschild, 2003). To improve their job marketability, artistic employees must accumulate job experience and constantly develop their skills, talent, and performance (Haunschild, 2003). 


\section{Data Collection and Analysis}

For data collection, we chose Konstanz Theater, which is owned by the city of Konstanz (population 80,000) in the south of Germany. Because the annual budget of 6 million euros is largely funded by the city, the communal administration has a voice in decisions on programming and resources and also appoints the theater manager and the administrative director. Konstanz Theater works with a permanent company of about one hundred employees, including an ensemble of twenty-two professional performers. Although theatrical plays are the mainstay, one or two musicals or short operas are produced each season. Children and youth theater programs also are offered. Operating with three parallel venues, Konstanz Theater realizes a mixture of the repertoire system and the en suite system. Persons involved in decisions on the theater's programming are the theater manager, stage director-in-chief, members of the dramaturgy, administrative director, and marketing director. Konstanz Theater represents a typical German public professional theater.

Semistructured interviews were conducted on the theater premises with the stage director-in-chief, two dramaturges, and the head of the marketing department. Because these people usually are involved in the decision making for the season, they are most knowledgeable about this process. The interviews lasted from 1 to $2 \frac{1}{2}$ hours and were transcribed verbatim. The data were separately analyzed by us and a master student who was involved in collecting the data. The results of the study were discussed with three members of other German communal theaters-a dramaturge, a stage directorin-chief, and a theater manager-to gauge to what extent the results can be considered typical.

\section{Required Programming Decisions}

Five decisions regarding a season's program were identified in the interviews: the theme, the selection of plays, the selection of stage directors, the cast selection, and the chronological order of productions.

\section{Season Theme}

Like many professional theaters, Konstanz Theater usually chooses a theme each season to constitute a thread tying the programming decisions together. From this seasonal theme, a motto is derived, such as "Russia" for a repertoire comprising mainly plays by Russian authors. Alternatively, the theme can refer to a particular event in the history of the theater or the local community, such as an anniversary. Apart from connecting the different contents and messages of the 
selected plays, the season's theme is the point of departure for marketing efforts.

\section{Selection of Plays}

The most important decision in developing a season's repertoire is the selection of plays to be performed. Usually, a reasonable mix of different genres of plays (that is, comedy, tragedy, tragicomedy) and different dates of origin (antique, classical, or modern) are sought. If a season theme has been chosen, plays are selected when their content or plot can be aligned with this theme. Another relevant criterion for play selection is the number of parts to be cast. Although less important parts can sometimes be written out of the script, the number of parts determines the amount of time and financial resources necessary for the production. Lastly, the popularity of a given play is an important criterion for the programming decision.

Usually, a reasonable mix of different genres of plays (that is, comedy, tragedy, tragicomedy) and different dates of origin (antique, classical, or modern) are sought.

\section{Selection of Stage Directors}

Similar to other German public theaters, stage directors are mostly engaged as guests for selected productions in Konstanz. Hence, the decision about a season's repertoire includes the choice of stage directors. This decision is guided first by a particular director's popularity and individual style. A highly prestigious director may stimulate the interest of a broad audience and thus promise high attendance levels. The selection of stage directors is usually guided by their previous productions or by established personal contacts. Second, the decision to work with a selected stage director depends on his or her availability. If a designated director is not available during a certain period, one option is to change the intended order of the productions in a season; another option is to switch to an available director with a comparable production style.

\section{The Cast}

The composition of the ensemble affects the decision about a season's repertoire because it limits the selection of plays that can be produced. Theater management usually aims at a fairly equal workload for all members of the ensemble. Deciding about the repertoire requires identifying ensemble members who could potentially be assigned to the selected productions. Thus, any stage director engaged for a certain production is usually confronted with a preselected choice of the ensemble. Criteria for decisions about the assignment are the performers' personal characteristics, such as gender, age, size, and voice, as well as their artistic ability, education, and experience. In addition, actors' working contracts 
sometimes guarantee one or two star parts during a season (Haunschild, 2003).

\section{Chronological Order of Productions}

Decisions regarding the chronological order of productions must take into account both new productions and reprises (productions introduced in a previous season). Like most communal theaters in Germany, Konstanz Theater has a subscription system that includes a certain number of premieres and ordinary performances. The number of premieres in a season must be matched with the scope of the premiere subscriptions. One criterion for scheduling a season's productions and performances is to achieve some alternation among the plays' different genres, epochs, and popularity. The order of productions must also be adjusted to visitors' leisure time preferences, which usually vary over the seasons.

Decisions about a theater season's theme, play selection, stage directors, the cast, and the chronological order of productions are mutually interdependent. When interpreting the interviews, we found every decision to be highly connected with every other decision, apart from the season theme. For example, the selection of plays depends on both the theme and the selection of stage directors. Similarly, the order of productions depends on the selection of stage directors and the cast.

\section{Consideration of Stakeholder Goals and Interests}

In the following, we analyze how the interviewed decision makers reflect on the goals and interests of the main stakeholders-local government, theater management, the audience, and artistic employees - and how they consider these goals and interests during the process of program planning.

\section{Local Government}

The local government's goal to educate citizens results in the wish for a broad and multifaceted repertoire that will draw large and varied audiences. According to the theater's marketing director, the local government "obviously requires a diversified program because it makes demands of its theater to reach a broad audience." Consequently, Konstanz does not specialize in a specific audience segment or a specific period. "Running a communal theater means producing theater for the city, that is, covering different age groups. Putting it more explicitly, it means addressing the very young with the children and youth theater, and reaching different

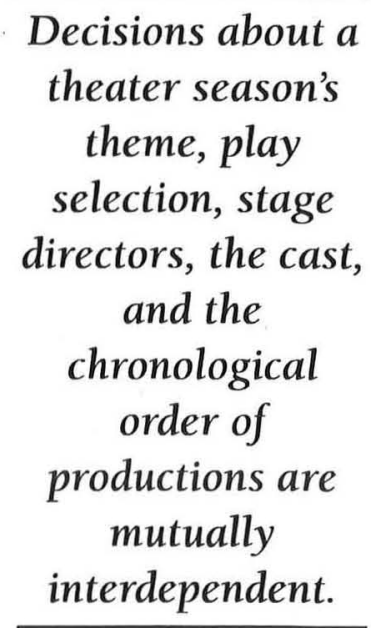




Another goal of
the local
government: to
reach not only
as many people as
possible, but also
as diverse a
population as
possible-mainly
in terms of age
and education
level.

classes of the population-actually, all citizens of the townsomehow with something" (stage director-in-chief). This quote points out another goal of the local government: to reach not only as many people as possible, but also as diverse a population as possible-mainly in terms of age and education level.

At the same time, a variety of restrictions follow from the local government's goal of economic efficiency. In particular, a certain number of paying visitors is expected: "Obviously, it is expected that the attendance does not fall below a certain level" (marketing director). Very important, too, is a certain number of subscriptions sold: The subscriber is "important for the local government. It wants to see ... many subscribers, bringing security. That's for sure" (marketing director). Therefore, Konstanz Theater must consider the potential audience's wishes and expectations in its program planning process. Due to financial restrictions set by the local government, Konstanz Theater is limited in its ability to hire guest directors and actors. Because it is restricted to its own ensemble, certain productions cannot be realized. "During reading, you have to check if you have the players in the ensemble. I just read a great play with six very young women and one man. However, we don't have six very young women" (stage director-in-chief).

The local government is also interested in the theater's image and thus expects a certain level of artistic quality. "The attendance level is not the only important point; the communal theater's image is important, too. That has to be protected" (marketing director). Summing up, "In my opinion, the local government demands good attendance levels, that the theater is more accepted by the citizens, that the theater constitutes a center of the city and is relevant, [and] that the theater is radiant to [outside visitors]" (stage director-inchief).

\section{Theater Management}

Theater management's main interest as an internal stakeholder lies in implementing its artistic vision. With regard to season program planning, this can mean focusing on a specific theme or topic. "We knew that our artistic director was very interested in Russian plays and that he would focus on that someday" (marketing director). To gain a reputation for high artistic quality, theater management often strives to produce unknown or contemporary plays outside the mainstream. "In-house, we clearly show a tendency toward the unknown" (stage director-in-chief). Theater management may also want to focus on socially relevant topics. "In my opinion, all theaters soon will deal with the school massacre topic. That is something that affects you, that makes you want to analyze what is going on.... Child neglect, too, is something that engages people" (stage director-in-chief). As a consequence, plays are selected for 
the season program that allow a stage director to deal with the topic of interest. "When I want to say something about globalization, I have to look for an adequate play. In that case, every theater is grateful for a play called Electronic City, which deals with this topic" (stage director-in-chief).

Another goal of theater management is to gain artistic recognition within the theatrical community. When planning the season program, theater management is mindful of how it will be perceived by colleagues and peers. Producing debut performances is one option for gaining national attention. "Yes, that's important indeed. . . You [must] offer something that attracts the supraregional media as well as your colleagues" (marketing director).

\section{Audience}

The theater audience wants to be entertained and have a good time. Comedies and easy-to-follow productions tend to be audience favorites. In one long-running production, Konstanz Theater included a local choir for its entertainment value. Some audiences also want to be educated and learn something new. The inclusion of plays by well-known authors, such as Schiller or Goethe, in a season's program is thus expected. "That simply is a wish of the visitors. Many want to see the classical repertoire" (marketing director). "Once in a while it is nice for a visitor when he can look up in the theater lexicon what he is going to see that evening. Even if he already has seen two productions of that play, he is able to compare the third one. That can be fun as well" (stage directorin-chief). Theater audiences also want to be surprised. "Being surprised and getting to see something completely new is nice, too. . . . I want to be surprised either by the play or by the way it is told. I want to be surprised and challenged by what I see" (stage directorin-chief). The audience's other goals of emotional arousal and social hedonism (meeting their peers and interacting socially in the theater) are not explicitly considered during program planning.

\section{Artistic Employees}

According to the stage director-in-chief, theater management takes into consideration the employees' desire to attain challenging assignments: "We try to achieve something like justice in the decisions about the casting. That does not mean that everybody is assigned a star role, but according to his stage of development, everybody should be given a bigger part in one production and a smaller part in another production."

Nearly all the stakeholder goals and interests identified in the literature (see Table 1) are considered by theater management in the process of program planning. The only exceptions are the employees' 


Conflicts exist
among artistic
excellence,
entertainment,
and economic
efficiency.

search for artistic excellence and the audience's desire for emotional arousal and social hedonism.

\section{Similarities and Differences Between Stakeholder Goals and Interests}

Similarities and differences among various stakeholder goals and interests can be identified. For example, high artistic ambitions are attributed to the local government, theater management, and artistic employees. In contrast, entertainment is a goal for the audience only, whereas artistic employees strive for challenging parts and theater management prefers the challenge of producing unknown works. Furthermore, goal conflicts become apparent. As predicted by the literature (Tajtáková, 2006a; Vakianis, 2006; Eikhof and Haunschild, 2007), conflicts exist among artistic excellence, entertainment, and economic efficiency. To prepare our analysis of the strategies that Konstanz Theater applies to cope with conflicting stakeholder goals, we briefly illustrate how these conflicts affect the theater's season planning by interpreting our interview data.

\section{Artistic Excellence Versus Economic Efficiency}

In Konstanz, stage directors typically are engaged as guests for a selected production. In its search for artistic excellence, theater management may want to hire highly respected stage directors who are known for their individual artistic style. However, such engagements are usually very costly and thus conflict with the goal of economical operation. Although a well-known and highly respected stage director may attract a broad audience, resulting in a high level of attendance and above-average revenues, theater management cannot be sure in advance.

\section{Artistic Excellence Versus Entertainment}

The production of little-known or contemporary plays constitutes a major artistic challenge and is thus highly appreciated by Konstanz Theater management. Theatergoers, however, generally prefer familiar plays, because a high level of familiarity reduces the risk of disappointment (Abbé-Decarroux, 1994). This preference has resulted in a shift of theater programming toward a more popular and less demanding repertoire (Heilbrun, 2001) and an increase in repertoire conformity in theater companies all over the world. This reaction to increasing financial pressures clearly leads neither to artistic excellence in general nor to the maintenance and refinement of theater plays in particular. In Konstanz, the play As It Is in Heaven (which featured a local choir) was produced primarily to raise attendance levels, at the expense of artistic quality. 


\section{Economic Efficiency Versus Entertainment}

Often, these two goals do not conflict but rather complement each other because fulfilling the audience's wish for entertainment usually results in increased attendance levels and revenues for the theater company. However, conflicts sometimes do occur. The audience in Konstanz generally greatly appreciates the casting of popular actors, often known from television. Engaging famous actors, however, is costly, and theater management usually cannot assess in advance whether the investment will pay off.

\section{Strategies to Manage Stakeholders' Conflicting Goals}

Balancing conflicting stakeholder goals means that theater managers must make trade-offs. To maximize the interests of all relevant stakeholders and simultaneously minimize the loss of support, theater managers must perform a complex balancing act. With regard to a season's programming, four options have been described by this study's interviewees: setting priorities, combining stakeholder interests, focusing on neutral goals, and developing the audience.

\section{Setting Priorities}

One way of managing conflicting stakeholder interests is to set priorities according to the stakeholders' different levels of relevance for the theater, by taking into account their power, legitimacy, and urgency (Schulenburg, 2006). In contrast to Schulenburg's (2006) analysis, the local community is regarded as most important by Konstanz Theater management, and its goals are given the highest priority during program planning. For example, more importance is attached to high attendance levels than to implementation of the management's artistic vision. "In the theater community you say that's just the way it is here" (marketing director). Accordingly, the local government holds a powerful influence. First, programming decisions must be approved by the communal administration; the local government has the right to refuse the theater management's plans for the season's program. Second, the communal administration appoints the theater manager and the administrative director. "Each artistic director applies with a concept ... and if he wants to stay for a while, he avoids conflicts with the local government to the extent possible and makes sure that the theater is full. If he doesn't care, he can do whatever he likes" (stage director-in-chief). In the long run, the audience is equally relevant for a theater company; without people sitting in the auditorium and watching the performances, theaters

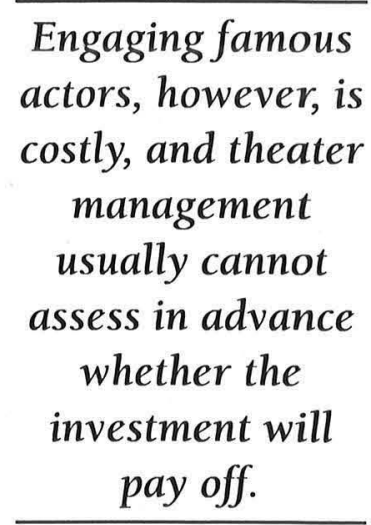


lose their legitimacy and their right to exist (Sauter, 2000; Jobst and Boerner, 2011). From a short-term perspective, however, the audience has much less power and influence, because theater management usually will not react to dissatisfied customers before attendance and subscription levels decrease considerably.

\section{Combining Stakeholder Interests}

A common strategy with regard to a theater's program planning is to include a variety of plays-satisfying as many stakeholders as possible. "A suggestion for the next season's motto was 'The Russians come!' meaning [that we would] produce many Russian plays. At a certain point, I said we can't dish up only Russian plays because Konstanz citizens then won't attend. They are not that interested. You can set highlights, for sure, but we have to make sure that there is a thriller, too, and a comedy" (marketing director). Another example is the combination of the local government's goal of reaching a broad audience with the theater management's interest in artistic quality: "It's all about having a good mixture. . . Y You have to make sure that you have plays with titles that are not too difficult or with interesting authors. ... That does not automatically mean producing bad theater. It can still be of high quality" (marketing director). "And then there is this compromise that we can afford to produce plays of unknown authors three or four times, but not constantly" (stage director-in-chief).

\section{Focusing on Neutral Goals}

Another way of managing diverse stakeholder interests is to focus on goals that do not negatively affect other stakeholders. One example concerning a season's program planning is the chronological order of productions; the only stakeholder with a main interest here is the audience-due to seasonal oscillations in its demands and expectations. In Konstanz, the season opening in autumn usually begins with a popular production. "For the opening of the season by all means a 'hit' to attract visitors. You need something that is popular in some way. And you definitely need favorable reviews. Right in the beginning, that's important" (marketing director). At the end of November, the Christmas season begins, providing many competing alternative events. Again, the marketing director gives an insight into these considerations: "The second production is relatively flexible. Last year, we had Brecht. And this year again Brecht and Yasmina Reza. Two popular plays. In October, the weather can still be nice. You are not immune to the loss of visitors, but by and by, you realize that attendance levels are rising and, in any case, it is important to make a lot [of revenue] in November and December. Performances where you can relax, where 
you really feel like going to the theater." Because January is the darkest month, a musical production can be a good choice. In February, the next "hit" may be placed. In spring, subscription for the next season begins. To commit existing subscribers and to convince new subscribers, popular plays of high quality are preferred. In summer, competing alternatives for leisure time appear, generally threatening attendance levels. In Konstanz, two alternative strategies are considered. On the one hand, by producing a very popular play, accompanied by intensive marketing efforts, the theater can try to compete with other leisure activities. This strategy, however, bears the risk that the high financial outlay will not be justified by equally high attendance levels. Alternatively, the theater can produce more experimental plays that generally attract fewer visitors. For theater management, adjusting the chronological order of the season's program according to the audience's leisure-time preferences is an outstanding opportunity to recognize the audience's goals and interests without hurting the other stakeholders.

\section{Developing the Audience}

A further way of managing conflicting stakeholder interestsmainly conflicts between theater management's search for artistic excellence and the audience's wish for entertainment-is audience development. Audience development is a proactive process of cultivating and growing long-term relationships by engaging, educating, and motivating diverse communities to participate in a creative, entertaining experience (Walker-Kuhne, 2001). Besides educational activities (Kawashima, 2000) and relationship-building techniques (Walker-Kuhne, 2001), marketing efforts by theaters seem to be an appropriate approach to developing their audiences (Hill, O'Sullivan, and O'Sullivan, 2003; Tajtáková and Arias-Aranda, 2008). "If I take a very modern play, for example, and have ten people supporting me to bring people into the theater, it can be successful. However, when I have a play and there is no time for advertisement it will end up a complete flop" (marketing director).

\section{Discussion}

Insights into the decision-making process behind theatrical season programming are rare. Because stakeholder interests in season program planning have not been considered in the literature, this article analyzes how these interests are managed in the planning process. Despite Europe's rich theater tradition, most studies on theater management thus far have been conducted in the United States. Therefore, we focus on public theaters in Germany.

Drawing on Schulenburg's (2006) analysis of stakeholders in German public theaters, the most relevant stakeholders are the local

\begin{tabular}{l} 
For theater \\
management, \\
adjusting the \\
chronological \\
order of the \\
season's program \\
according to the \\
audience's leisure- \\
time preferences is \\
an outstanding \\
opportunity to \\
recognize the \\
audience's goals \\
and interests \\
without hurting \\
the other \\
stakeholders. \\
\hline
\end{tabular}


government, theater management, the audience, and artistic employees. Based on existing literature on the German theater system, the goals of these stakeholders are artistic excellence, educational functions, entertainment, and economic efficiency. Our analysis reveals both similarities and differences among stakeholder goals. Although the goal of artistic excellence is shared by the local government, theater management, and artistic employees, economic efficiency is pursued exclusively by the local government. The educational functions of a theater are a goal only for the local government and the audience. Entertainment as a goal is exclusive to the audience.

Our analysis of Konstanz Theater describes the subjects of decision making-season theme, selection of plays, selection of stage directors, cast selection, and chronological order of productions - and their respective interdependences. Moreover, we analyze how stakeholder goals are considered by theater management in the decisionmaking process. With the exception of the artistic employees' search for artistic excellence and the audience's desire for emotional arousal and social hedonism, all stakeholder goals are explicitly considered in the theater's program planning. However, the employees' quest for artistic excellence is implicitly considered when theater management tries to achieve justice in casting decisions. The audience's desire for emotional arousal is not explicitly mentioned, perhaps because arousing emotions is one of the theater's most traditional functions and thus may be self-evident. In contrast, the audience's desire for social hedonism, or social interaction, is not explicitly mentioned for two reasons. First, theatergoing is not an activity geared exclusively to meeting peers and interacting socially; second, opportunities for social interaction with peers can only marginally be influenced by the central subjects of program planning: season theme, play selection, stage directors, cast members, and production chronology.

As expected from the literature, goal conflicts exist among artistic excellence, entertainment, and economic efficiency. Interpreting our interview data, we found illustrations of how these conflicts affect Konstanz Theater's season planning. Finally, we identified four strategies applied by theater management to balance conflicting stakeholder goals in the process of season programming: setting priorities, combining stakeholder interests, focusing on neutral goals, and developing the audience.

Our study is the first to analyze how stakeholder goals and interests are considered in the process of planning a theater season. Our results suggest that theater management is well aware of conflicting stakeholder goals, and that theater management has developed different strategies to manage competing stakeholder goals.

Due to the small database, the results of our study are rather tentative. Nevertheless, it may inspire future research on stakeholder management in theaters. Additional interviews should first be conducted in other German public theaters to discover other strategies 
for managing conflicting stakeholder goals. Second, given the considerable particularities of the German theater system, similar studies should be conducted in other countries such as the United States and Great Britain, including for-profit theaters. Third, although our analysis is easily applicable to nonprofit organizations, including future privatized theaters in Germany, differences in the results are to be expected. For example, the local government is a less important stakeholder for nonprofit theaters than for public theaters; consequently, setting priorities will be a more relevant strategy for managing conflicting stakeholder goals. Therefore, comparisons between for-profit and nonprofit theaters concerning stakeholders' roles in program planning could contribute to the small body of research regarding stakeholder management in theaters. Fourth, it could be worthwhile to apply our approach of stakeholder analysis to other organizations in the performing arts sector.

Regarding practical implications, Konstanz Theater does not have explicit stakeholder management. Instead, different theater stakeholders and their goals seem to be implicitly present during the process of program planning. Given the rising economic pressure on public theaters in Germany (Vakianis, 2006), including stakeholders more directly in the process of decision making might be wise. Representatives of the local government, the audience, and artistic employees could be invited to participate in the process, thus allowing these external stakeholders to explain and discuss their expectations.

\section{References}

Abbé-Decarroux, F. "The Perception of Quality and the Demand for Services. Empirical Application to the Performing Arts." Journal of Economic Behavior and Organization, 1994, 23(1), 99-107.

Assassi, I. "The Programming Strategies and Relationships of Theatres: An Analysis Based on the French Experience." International Journal of Arts Management, 2007, 9(3), 50-64.

Auvinen, T. "Why Is It Difficult to Manage an Opera House? The Artistic-Economic Dichotomy and Its Manifestations in the Organizational Structures of Five Opera Organizations." Journal of Arts Management, Law and Society, 2001, 30(4), 268-282.

Bouder-Pailler, D. "A Model for Measuring the Goals of Theatre Attendance." International Journal of Arts Management, 1999, 1(2), $4-15$.

Choi, J., and Wang, H. "Stakeholder Relations and the Persistence of Corporate Financial Performance." Strategic Management Journal, 2009, 30(8), 895-907.

Deutscher Buehnenverein. (2010). Theaterstatistik 2008/09 [Theatre Statistic 2008/2009]. Koeln, Germany: Mykenae Verlag.
The local government is a less important stakeholder for nonprofit theaters than for public theaters; consequently, setting priorities will be a more relevant strategy for managing conflicting stakeholder goals. 
DiMaggio, P. "Nonprofit Organizations in the Production and Distribution of Culture." In W. Powell (ed.), The Nonprofit Sector: Research Handbook. New Haven, Conn.: Yale University Press, 1987.

DiMaggio, P., Useem, M., and Brown, P. Audience Studies of the Performing Arts and Museums: A Critical Review. Washington, D.C.: National Endowment for the Arts, 1978.

Eikhof, D. R., and Haunschild, A. "For art's sake! Artistic and economic logics in creative production." Journal of Organizational Behavior, 2007, 28(5), 523-538.

Freeman, R. E. Strategic Management: A Stakeholder Approach. Boston: Pitman, 1984.

Gainer, B., and Padanyi, P. "Applying the Marketing Concept to Cultural Organisations: An Empirical Study of the Relationship Between Market Orientation and Performance." International Journal of Nonprofit and Voluntary Sector Marketing, 2002, 7(2), 182-193.

Gilhespy, I. "Measuring the Performance of Cultural Organizations: A Model." International Journal of Arts Management, 1999, 2(1), 38-52.

Haunschild, A. "Managing Employment Relationships in Flexible Labour Markets: The Case of German Repertory Theatres." Human Relations, 2003, 56(8), 899-929.

Heilbrun, J. "Empirical Evidence of a Decline in Repertory Diversity among American Opera Companies 1991-92 to 1997-98." Journal of Cultural Economics, 2001, 25(1), 63-72.

Hill, E., O'Sullivan, C., and O'Sullivan, T. Creative Arts Marketing. Amsterdam: Elsevier Butterworth-Heinemann, 2003.

Hoegl, C. Ökonomie der Oper. Grundlagen für das MusiktheaterManagement [Economics of Opera: Fundamentals for Music Theatre Management]. Bonn: ARCult Media, 1995.

Jobst, J., and Boerner, S. "Understanding Customer Satisfaction in Opera. First Steps toward a Model." International Journal of Nonprofit and Voluntary Sector Marketing, 2011, 16(1), 50-69.

Kawashima, N. "Beyond the Division of Attenders and Non-attenders. A Study into Audience Development in Policy and Practice." In O. Bennett (ed.), Research Paper No. 6. Coventry, England: Centre for Cultural Policy Studies, University of Warwick, 2000.

Martorella, R. "The Relationship Between Box Office and Repertoire: A Case Study of Opera." The Sociological Quarterly, 1977, 18(3), 354-366.

Mitchell, R. K., Agle, B. R., and Wood, D. J. "Toward a Theory of Stakeholder Identification and Salience: Defining the Principle of Who and What Really Counts." The Academy of Management Review, 1997, 22(4), 853-886.

Orlitzky, M., Schmidt, F. L., and Rynes, S. L. "Corporate Social and Financial Performance: A Meta-analysis." Organization Studies, 2003, 24(3), 403-441. 
Pierce, J. L. "Programmatic Risk-Taking by American Opera Companies." Journal of Cultural Economics, 2000, 24(1), 45-63.

Rentschler, R., Radbourne, J., Carr, R., and Rickard, J. "Relationship Marketing, Audience Retention and Performing Arts Organisation Viability." International Journal of Nonprofit and Voluntary Sector Marketing, 2002, 7(2), 118.

Roman, R. M., Hayibor, S., and Agle, B. R. "The Relationship between Social and Financial Performance: Repainting a Portrait." Business Society, 1999, 38(1), 109-125.

Ruf, B. M., Muralidhar, K., Brown, R. M., Janney, J. J., and Paul, K. "An Empirical Investigation of the Relationship between Change in Corporate Social Performance and Financial Performance: A Stakeholder Theory Perspective." Journal of Business Ethics, 2001, 32(2), 143-156.

Sauter, W. The Theatrical Event. Dynamics of Performance and Perception. Iowa City: University of Iowa Press, 2000.

Schugk, M. Betriebswirtschaftliches Management öffentlicher Theater und Kulturorchester [Business Management of Public Theatres and. Orchestras]. Wiesbaden: Deutscher Universitaetsverlag, 1996.

Schulenburg, S. "Die Rolle der Besucher und anderer Kunden für Kulturbetriebe am besonderen Beispiel des Theaters [Relevance of Visitors and Other Customers for Cultural Organizations Using the Example of Theatres]." In A. Hausmann and S. Helm (eds.), Kundenorientierung im Kulturbetrieb. Grundlagen - Innovative Konzepte - Praktische Umsetzung [Customer Orientation in Cultural Organizations]. Wiesbaden: Verlag für Sozialwissenschaften, 2006.

Statistische Aemter des Bundes und der Laender. (2008). Kulturfinanzbericht 2008 [Financial Report of Culture 2008]. Wiesbaden: Statistisches Bundesamt.

Tajtáková, M. "Conflicting and Overlapping Nature of Strategic Objectives in an Opera House Management: Implications for a New Management Model." Paper presented at the Association for Cultural Economics International, Vienna, Austria, July 2006a.

Tajtáková, M. "Flexibility of Strategic Choices in an Opera House Management." International Journal of Business Environment, 2006b, 1(3), 365-381.

Tajtáková, M., and Arias-Aranda, D. "Targeting University Students in Audience Development Strategies for Opera and Ballet." Service Industries Journal, 2008, 28(2), 179-191.

Turbide, J., and Laurin, C. "Performance Measurement in the Arts Sector: The Case of the Performing Arts." International Journal of Arts Management, 2009, 11(2), 56-70.

Vahs, D., and Schäfer-Kunz, J. Einführung in die Betriebswirtschaftslehre [Introduction to Business Management]. Stuttgart: SchaefferPoeschel, 2007.

Vakianis, A. "Besonderheiten des Managements von Kulturbetrieben anhand des Beispiels Theater [Special Characteristics of Managing Cultural Institutions Using the Example of Theatres]." 
In T. Zembylas and P. Tschmuck (eds.), Kulturbetriebsforschung. Ansätze und Perspektiven der Kulturbetriebslehre [Research in Cultural Management: Approaches and Perspectives of the Management of Cultural Industries]. Wiesbaden: Verlag für Sozialwissenschaften, 2006.

Voss, G. B., Sirdeshmukh, D., and Voss, Z. G. "The Effects of Slack Resources and Environmental Threat on Product Exploration and Exploitation." Academy of Management Journal, 2008, 51(1), 147-164.

Voss, G. B., and Voss, Z. G. "Strategic Orientation and Firm Performance in an Artistic Environment." Journal of Marketing, 2000, 64(1), 67-83.

Voss, Z. G., and Voss, G. B. "Exploring the Impact of Organizational Values and Strategic Orientation on Performance in Not-for-Profit Professional Theatre." International Journal of Arts Management, 2000, 3(1), 62-76.

Voss, Z. G., Voss, G. B., and Moorman, C. "An Empirical Examination of the Complex Relationships between Entrepreneurial Orientation and Stakeholder Support." European Journal of Marketing, 2005, 39(9/10), 1132-1150.

Walker-Kuhne, D. "Building Community-Based Audiences for the Arts." Part 1 and 2, 2001. Retrieved May 24, 2008, from http://arts marketing.org

SABINE BOERNER is the chair of management, especially strategy and leadership, at the University of Konstanz, Germany.

JOHANNA JOBST is a research associate in the Department of Politics and Management at the University of Konstanz, Germany. 